\title{
Impact of Green Human Resources Practices on Green Work Engagement in the Renewable Energy Departments
}

\author{
Ayman Alshaabani ${ }^{1}$, Farheen $\mathrm{Naz}^{1}$, \& Ildikó Rudnák ${ }^{2}$ \\ ${ }^{1} \mathrm{PhD}$ candidate, Institute of Economics, Hungarian University of Agriculture and life sciences, Gödöllo, \\ Hungary \\ ${ }^{2}$ Associate Professor, Institute of Social Sciences, Hungarian University of Agriculture and life sciences, \\ Gödöllo, Hungary \\ Correspondence: Ayman Alshaabani, $\mathrm{PhD}$ candidate, Institute of Economics, Hungarian University of \\ Agriculture and life sciences, Gödöllo, Hungary.
}

Received: March 4, 2021

Accepted: March 29, 2021

Online Published: May 12, 2021

doi:10.5539/ibr.v14n6p44

URL: https://doi.org/10.5539/ibr.v14n6p44

\begin{abstract}
In recent years, the sense of responsibility among companies and organizations has increased manifold because of external pressure towards environmental sustainability. There are several measures taken by the organizations to work in a green or eco-friendly manner, and among these measures, green human resources management has become an important practice of an organization. This study explores the role of Green human resources management (green HRM) in predicting the green work engagement (GWE) of employees. The study surveyed employees from three big energy companies that operate in Hungary. The research focused on four main practices of Green HRM and aimed to find out whether they can predict green work engagement. In this study, self-administered questionnaires were used as a tool for collecting the data through online channels, and around 238 employees responded to fill out the questionnaire. After collecting the data, hypotheses were tested by using SEM analysis to fulfill the study's objectives. The results indicated that only green rewards, green training, and green performance management significantly predicted GWE. In contrast, green performance management was not a significant predictor of GWE. The study tries to bring better understanding for the managers, policymakers, and future researchers to identify the role of these practices in an organization.
\end{abstract}

Keywords: green HRM, engagement, human resources, employee's behavior, Hungary

\section{Introduction}

In the current scenario of globalization, growth and development became the foremost agenda of organizations and companies. Increasing industrial activities, as well as human consumption patterns and their detrimental impact on the environment, has become the topic of debate among scientists, environmentalists, and policymakers. The issues related to climate change, rising global temperature, deforestation and wildfires, increasing pollution worldwide are some global problems that require immediate and consistent action to mitigate these climate urgencies (Naz, Oláh, Vasile, \& Magda, 2020). In this regard, marketers and policymakers recommend measures and practices to be incorporated by businesses and firms that reduce their carbon footprints, and hence the term green business came into existence. Nowadays, green businesses are termed big businesses. It is regarded as an advantage for the organization if it is referred to as green. It enhances its competitive advantage, brand image, increases margins, and reduced operational cost. It also provides long-term benefits, for instance, no more dependence on virgin materials. Therefore, many businesses and organizations are willing to promote their environmental accords (Kane, 2011).

The quality of the environment and its influence on human beings witnessed to be an important topic of research in the past several years. The incorporation of practices involving a sustainable environment is becoming crucial for the competitive advantage and image of an organization (Paillé, Chen, Boiral, \& Jin, 2014; Tang et al., 2018). The different facets of the business have been influenced by going green agenda such as marketing, operation management, accounting, and management (Ziegler \& Seijas Nogareda, 2009). Human resource management (HRM) is considered as the most valuable and foremost division of an organization that encompasses human resources, which regarded as essential assets, also got influenced by the trend of going green (Ahmad, 2015). 
There is a shift in the strategies and concerns of organizations in the direction of sustainable and green-orientated motives. In this regard, the human resource management (HRM) managers are bound to restructure their goal and enhance their practices with the incorporation of green management methods, which will create improvement in the way of their basic HRM methods (Alshaabani \& Rudnak, 2020; Ángel del Brío, Junquera, \& Ordiz, 2008). It was proposed by Pham, Paillé, and Halilem (2019) that HRM can measure and affect the behaviours of employees in terms of sustainability-associated attitudes, behaviours, motivation, and awareness. Hence, organizations can use HRM in order to develop or generate effective eco-friendly practices (Renwick, Redman, \& Maguire, 2013), while it can be accomplished through the different activities of human resources that intend to bring into practice the policies of green human resource (Renwick, Redman, \& Maguire, 2008).

Many studies have proved that for environmental management initiatives the involvement of employees in green practices is essential (Jabbour, Santos, \& Nagano, 2008), and it will further contribute to the improved competitive advantage and environmental performance (Kim, Kim, Choi, \& Phetvaroon, 2019). In terms of green performance behaviours, it is believed that green HRM can influence the performances of employees related to environmental aspects (Chaudhary, 2020). In a study conducted by Zoogah (2011), Green Human Resources Management (green HRM) was defined as the utilization of the HRM policies, practices, and philosophies in order to encourage the sustainable usage of the resources involved in a business and prevent any detrimental impact on the environment. In the past few years, environmental management and green practices became a fundamental and important part of many organizations. Considering this, the green behaviours of employees are regarded as one of the strategies of an organization to attain sustainability goals and to enhance its environmental performance (DuBois \& Dubois, 2012). Green behaviours can be defined as the behaviours exhibited by employees that can affect the environment in a positive way (Unsworth, Dmitrieva, \& Adriasola, 2013).

Also, the behaviours of employees that encourage the environmental management practices at their office are referred to as green behaviours (Dumont, Shen, \& Deng, 2017). It is considered that the green behaviour of employees is the fundamental evidence that there is effective execution of green practices and policies in the organization. It is believed that green human resources management (green HRM) methods are a necessary HRM policy to encourage green employees and to increase their awareness towards environment. The activities of green HRM to promote environmental management involve numerous functions like green recruitment, green rewards, green performance appraisal, and green training (Dumont et al., 2017; Renwick et al., 2013; Tang et al., 2018). The practices of green HRM are used as a means to forecast distinct green behaviours among employees (Halawi \& Zaraket, 2018), for instance, environment-friendly actions of employees (Kim et al., 2019), green official behaviour, and organizational citizenship behaviour (Opatha \& Arulrajah, 2014), along with green work engagement (GWE) (Aboramadan, 2020). GWE is defined as "the energy an employee puts in his green work-related tasks, the willingness to exert efforts at the green level, and the green work's absorption level." (Aboramadan, 2020, p.4).

For the execution and creation of green practices, HRM provides a significant role and it also indicates its involvement in green work engagement. Hence, it can be assumed that to achieve better work efficiency, increased employee engagement, and reduced cost, the GHRM is an important environment-friendly initiative (Ranasinghe \& Welmilla, 2020). In this regard, an initiative has been taken in order to investigate the influence of green HRM procedures to analyse the GWE among the employees working in three different energy companies. The study has been conducted in Hungary, and the reason to choose the energy sector located in Hungary is that the targeted companies have renewable energy departments and the studied green HRM practices are being performed in their departments. The researchers employ the perceived GHRM measures to evaluate their impact on analysing the GWE in the context of Hungary. The green HRM related research has prospered in the past several years including numerous studies done in different industries, for instance, hospitality and tourism (Luu Tuan, 2017), automobile industry (Chaudhary, 2019), and information and technology (Ojo \& Raman, 2019). Although, very few studies determined GWE with green HRM as a predicting variable (Aboramadan, 2020). Hence, this study attempts to fulfill the research gap by exploring the impact of each green HRM practice individually on GWE among the employees of selected renewable energy departments in Hungary. The goal of the study is to explore the effect of green HRM practices to enhance the GWE among employees. To analyse the data and to evaluate the relationship between the variables, structural equation modeling (SEM) has been used.

\section{Literature Review}

\subsection{Green HRM Practices}

Green HRM is referred to as the combination of practices that HRM uses like recruitment and selection, performance appraisal, training and development, and reward systems to attain the organization's green objectives 
(Haddock-Millar, Sanyal, \& Müller-Camen, 2016). To achieve environmental goals, green HRM is used as a green strategy by organizations (Yusoff, 2016), and also to make an ecological balance and protect the environment it regarded as a part of green management of an organization (Goswami \& Ranjan, 2015). Green HRM describe as to "the systematic, planned alignment of typical human resource management practices with the organization's environmental goals" (Jabbour, 2013, pp. 147-148). According to Opatha and Arulrajah (2014), green HRM referred to it as "all the activities involved in development, implementation and on-going maintenance of a system that aims at making employees of an organization green. It is the side of HRM that is concerned with transforming normal employees into green employees so as to achieve environmental goals of the organization and finally to make a significant contribution to environmental sustainability. It refers to the policies, practices and systems that make employees of the organization green for the benefit of the individual, society, natural environment, and the business."p.104.

Green HRM practices focus on improving the workers' abilities, information, and behaviors to achieve environmental objectives. Furthermore, to gain progressive improvements between operational employees and leaders related to the environmental procedures along the organizations' value-chain that permit to lessen waste, spare power, and assets (Arulrajah, Opatha, \& Nawaratne, 2015). Previous scholars contend that the way in which human resource management is rendered green is subjective to all HRM practices such as, job description and analysis, training development, selection and recruitment, performance management, and rewards and pay (Renwick et al., 2013). The main green HRM practices that this research will study are:

\subsubsection{Green Training}

Green training is "a practice that focuses on development of employees' skills, knowledge, and attitudes, prevents deterioration of EM (environment management) related knowledge, skills, and attitudes. Activities that educate employees about the value of EM, train them in working methods that conserve energy, reduce waste, diffuse environmental awareness within the organization, and provide opportunity to engage employees in environmental problem-solving." (Zoogah, 2011, p.133). Providing green training for the employees and managers is important for organizations to change the attitudes and behaviors of its employees and managers to become green (North, 1997). It has a significant relationship with creating green behavior between employees (Zoogah, 2011). Green training plays an important role in making the employees' well prepared for challenges and changes in the workplace, motivating them to be more engaged in their job Jabbar and Abid (2015). Green training also indirectly enhances employees' engagement by enhancing the employees' work motivation toward participating in green activities, which eventually assist in creating organizational employee engagement systems (Curkovic, Melnyk, Handfield, \& Calantone, 2000). Green training practices are also important to improve the employees' engagement for the newly hired employees (Jyoti, 2019).

\subsubsection{Green Reward System}

Rewards seek to attract, retain, and motivate employees who could achieve the best performance. They also seek to motivate employees to gain new skills, knowledge, and actions that lead to attaining organizational goals (Jerez-Gómez, Céspedes-Lorente, \& Valle-Cabrera, 2005). Rewards are considered important tools in linking corporate interests with persons' interests. Rewards can change employees' focus toward the essential segments of their job and inspire them to give their best (Jackson, Renwick, Jabbour, \& Muller-Camen, 2011). When an organization uses green job performance appraisal for its employees, it tends to reward the employees with some green rewards and pensions, which help establish green performance management (Aktar \& Islam, 2019). Green rewards were described as "the implementation of a system of financial and non-financial rewards for employees with a distinct potential to contribute to environmental management" (Jabbour et al., 2010, p.1058). These definitions were proved by (Jackson et al., 2011), who found that monetary and nonmonetary rewards play a unique role in assisting environmental management activities. And when employees participate in these environmental activities, they tend to have higher green behaviors (Chaudhary, 2020). Different studies have found a relationship between green rewards and employees' engagement in an environmental context (Aktar \& Islam, 2019). Green rewards and pensions systematically motivate employee engagement positively (Ahmed, AlZgool, \& Shah, 2019; Daily \& Huang, 2001; Renwick et al., 2013). According to Ahmad when organizations apply green reward systems in their HRM process, a preferred green behaviours will promote among their employees, furthermore, their employees may be more engaged in the decision making process when their managers ask their opinions related to the green objectives (Ahmad, 2015).

\subsubsection{Green Performance Management}

According to Ahmad (2015), performance management is defined as "the process by which employees are prompted to enhance their professional skills that help to achieve the organizational goals and objectives in a 
better way" p6. With environmental management influencing the global business strategies of the organizations, the performance management is also positively influenced by the green wave. Hence, some of the companies make a standard for the environmental goals and evaluate the contribution of the employees for environmental management, and these companies make it as a criteria for the employees in the performance appraisal program (Ahmad, 2015; Jabbour, 2011). Green performance management systems encourage employees and improve their abilities to accomplish green organizational objectives in a better way (Ahmad, 2015). And this can be done through green performance assessment, which is defined as 'the appraisal and registration of employees' environmental performance throughout their careers in a company and provides them with feedback about their performance to prevent undesirable attitudes or reinforce exemplary behavior" (Jabbour et al., 2010, p. 1057). Effective green performance management systems provide efficient feedback for employees and assist the organization's environmental objectives with continuous improvements (Jackson et al., 2011).

Engaging employees in the decision-making for the green activities help in enhancing employees' performance. And when a performance management system is rewarding green activities, it helps in building green performance . Besides, when employees are conscious of the green HRM practices applied in their organization, they are more engaged in decision making and more motivated to achieve high green performance (Jabbar \& Abid, 2015; Renwick et al., 2013). When an organization engages all its employees in different segments of work and support them to participate in green HRM practices, it can achieve its green objectives (Jabbar \& Abid, 2015).

\subsubsection{Green Recruitment and Selection}

Attracting first-class employees is a major challenge for HR in their fight to attract talents. As a result of the rapidly increased environmental awareness, a recruiting company's green reputation and image play a fundamental role in recruitment motives. The people who are seeking employment prefer those organizations that are closer to their personal beliefs, and green values are among the most common values, especially for young generations, for this, some employers are adopting Green HRM practices to help in building this green image (Renwick et al., 2013). According to Ahmad (Ahmad, 2015), green recruitment can be referred as "The process of hiring individuals with knowledge, skills, approaches, and behaviors that identify with environmental management systems within an organization." (p.6).

There are three categories for green recruitment that are set by (Tang et al., 2018): (a) green employer branding, (b) candidates' green awareness, and (c) green measures utilized to entice applicants. They indicated that green awareness of the candidate could support organizations in achieving their objectives regarding environment; on the other hand, green employer branding can help in attracting the potential talented workers; green criteria are important in evaluating and selecting employees based on their green values. Recruiting candidates with green awareness opens doors for companies to induct highly skilled employees who are mindful of sustainable methods and are already used to know the basics of sustainability principles (Ahmad, 2015).

According to (Jabbour et al., 2010), green selection refers to the "selection of people committed and sensitive to the environmental issue, with a potential contribution to the environmental management of a company" (p.1057). therefore, environmental management-oriented organizations should select people with high commitment and sensitivity toward environmental issues (Jabbour, 2011).

\subsection{Green Work Engagement}

Work engagement can also reflect the employees' cognitive commitment, emotional attachment, and behavioral drivers to develop the person's aggregated aspects of role performance (Saratun, 2016). Other researchers focused on work engagement as a positive state of mind like (Schaufeli, Salanova, González-romá, \& Bakker, 2002), who defined work engagement as "a positive, fulfilling, work-related state of mind that is characterized by vigor, dedication and absorption" (p. 74). Vigor is characterized as the high level of enthusiasm and great spirit whilst at work in one's organization or workplace, also to be able to give sufficient energy to the job by the employee, besides the determination an employee shows to confront the obstacles at work. On the other hand, dedication implies to broaden the challenging feelings an employee might experience at work, which is complemented by the feelings of pride, passion and support at the workplace. While absorption refers to being completely focused and immensely engaged in one's work, as time quickly passes and he or she feels that time is flying while at work and find it difficult to separate oneself from work (Schaufeli et al., 2002). The level of connection of employees to their work in terms of emotionally, cognitively and physically refer to Engagement.

Depending on what was mentioned, Green employee engagement could be described as "the energy an employee puts in his green work-related tasks, the willingness to exert efforts at the green level, and the green work's absorption level." (Aboramadan, 2020, p.4). 


\subsection{Green HRM and GWE}

Having green HRM practices would promote green objectives and encourage positive work behaviors (Hobfoll, 2001; Jabbar \& Abid, 2015). Organizations with good green HRM practices like green reward (GR), green performance management (GPM), green training (GT), green selection and recruitment (GSR), and green employment relations (GER) can affect employees' behaviors toward being green (Rani \& Mishra, 2014; Renwick et al., 2013). Similarly, Cantor, Morrow, and Montabon (2012) found that green work engagement results from supervisors' support and good human resources management practices like green rewards and green training. This goodness in Green HRM will motivate employees, enhance their skills to demonstrate constructive green behaviors, and persuade them to establish new ideas and to come up with new solutions at the green level (Aboramadan, 2020). Green HRM can also have a motivational role in both extrinsically and intrinsically in supporting the employees' development and adding to their career aspirations as an accomplishment, which will promote the dedication toward work between the employees (Bakker Arnold \& Demerouti, 2008) and especially GWE (Aboramadan, 2020; Arasli, Nergiz, Yesiltas, \& Gunay, 2020). Similarly, Cantor et al. (2012) found that green work engagement results from supervisor's support and human resource management practices like green rewards and green training. A vital outcome of GHRM is GWE because such practices are evaluated by employees as constructive impacts and events in an organization (Ari, Karatepe, Rezapouraghdam, \& Avci, 2020). Moreover, it was found that GWE could mediate the impact of GHRM on green individual behaviors on green individual behaviors (Ababneh, 2021), green pro-environmental behaviors (Ari et al., 2020), in role green behavior and extra-role green behaviors (Aboramadan, 2020)

From an environmental sustainability viewpoint, GWE is very important for organizations' environmental sustainability; this engagement can result from obtaining a green reward system, green training, and supportive management behaviors, which creates commitment of employees toward green activities (Welmilla \& Ranasinghe, 2020). Green HRM practices can also influence green employees' engagement through having sustainability goals and corporate social responsibility within organizations (Casey \& Sieber, 2016).

Based on this, the researchers set one hypothesis, with four sub-hypotheses to achieve the study objectives:

H1: Green HRM significantly predicts GWE.

To test this hypothesis, the researchers set four sub-hypotheses:

H1-1 Implementing green rewards can predict GWE significantly.

H1-2 Implementing green performance management can predict GWE significantly.

H1-3 Implementing green training can predict GWE significantly.

H1-4 Implementing green selection and recruitment can predict GWE significantly.

\section{Research Methodology}

\subsection{Sampling Method}

In this study, the targeted population was the employees of three big energy companies which deal with renewable energy and are operating in Hungary. These three companies have its branches inside and outside of Hungary and dealing with energy sector with different products. In the HR departments of each of these companies the green HRM practices are being applied, and each of these companies have renewable energy department. The study was focused on the employees of these departments because mostly these employees perceived green practices in comparison to the employees of other departments as clarified by the HR supervisors of the companies.

The questionnaire was sent as an electronic form to the employees along with a cover letter stating the study's purpose with the help of the HR department of respective companies. The data was collected between January to March 2020; the study used self-administered questionnaires with closed-ended items to gather data. In total, 450 questionnaires were distributed. Out of 450 questionnaires, only 238 responses were received, complete and valid. Later the data were automatically generated in an Excel sheet and manually entered in the SPSS database, and ready to use in the study analysis.

\subsection{The Instrument}

The questionnaire consisted of three parts. The first section of the questionnaire consists questions regarding employee's personal characteristics like gender, age, job tenure, and job level.

The second section had 13 items covering the four studied dimensions of Green HRM; this section was adapted from previous studies (Jabbour et al., 2010; Tang et al., 2018). These 13 items were distributed to cover four factors (green training, green recruiting and selecting, green performance, green rewards). The third part of the 
questionnaire was about GWE using six items adopted from the study (Aboramadan, 2020). In the second section, five-point Likert scale-based questions were used with values ranging from 1 to 5 symbolizing totally disagree to totally agree, respectively. Whereas, in the third section, seven-points Likert scale-based was used with range of values ( 1 is totally disagree to 7 totally agree). Table 1 shows the scales of the independent and dependent variables of the study.

Table 1. The study's variables scale

\begin{tabular}{|c|c|}
\hline Dimension & Items \\
\hline \multicolumn{2}{|r|}{ Independent variables } \\
\hline \multirow{2}{*}{ Green rewards } & Environmental performance is financially rewarded * \\
\hline & Environmental performance is publicly recognized ${ }^{*}$ \\
\hline \multirow{3}{*}{ Green training } & $\begin{array}{l}\text { Training programs are provided for employees to increase their environmental } \\
\text { awvareness, skills, and experience * }\end{array}$ \\
\hline & $\begin{array}{l}\text { In our company, everybody has an equal opportunity to receive training on } \\
\text { environmental management aspects * }\end{array}$ \\
\hline & Environmental training is recurring in the company ${ }^{*}$ \\
\hline \multirow{5}{*}{$\begin{array}{l}\text { Green Performance } \\
\text { management }\end{array}$} & $\begin{array}{l}\text { In our company, there are dis-benefits in the performance management system for } \\
\text { non-compliance or not meeting environment management goals } *\end{array}$ \\
\hline & Managers' set of objectives on achieving green outcomes are included in evaluations* \\
\hline & $\begin{array}{l}\text { The company sets green targets, goals, and responsibilities for managers and } \\
\text { employees** }\end{array}$ \\
\hline & Individual environmental appraisals are registered $*$ \\
\hline & Environmental performance of the company enhances employees $* *$ \\
\hline \multirow{3}{*}{ Green recruitment } & Our company prefers to recruit employees who have green awareness $* *$ \\
\hline & Selection considers employee's environmental motivation * \\
\hline & All phases of selection consider environmental issues * \\
\hline \multicolumn{2}{|r|}{ Dependent variables } \\
\hline \multirow{6}{*}{$\begin{array}{l}\text { Green work } \\
\text { Engagement }\end{array}$} & I am proud of the environmental work that I do \\
\hline & I am enthusiastic about my environmental tasks at my job \\
\hline & I am immersed in my environmental work \\
\hline & I feel happy when I am working intensely on environmental tasks \\
\hline & With environmental tasks at my job, I feel bursting with energy \\
\hline & My environmental- related tasks inspire me \\
\hline
\end{tabular}

Sources of the items: GWE (Aboramadan, 2020), GHRM * (Jabbour et al., 2010)** (Tang et al., 2018)

\subsection{Reliability Test}

The reliability test has been conducted before analyzing the results in which Cronbach's alpha equation examined the internal consistency of the study's dimensions. This was based on the calculation for all dimensions above 0.6, indicating an acceptable reliability level (Sekaran \& Bougie, 2016). Table 2 shows the reliability test results.

Table 2. The Reliability tests

\begin{tabular}{lccc}
\hline Variable & No. Items & $\begin{array}{c}\text { Cronbach's } \\
\text { alpha }\end{array}$ & Result/pass \\
\hline Green rewards & Independent variables & & \\
Green training & 2 & 0.63 & yes \\
Green performance & 3 & 0.81 & yes \\
Green recruitment & 5 & 0.85 & yes \\
\hline GWE & 3 & 0.75 & yes \\
\hline
\end{tabular}




\subsection{Validity Test}

After conducting reliability analysis, the validity test has been conducted to test the validity of the data under study. To test and check the variables, confirmatory factor analysis (CFM) has been applied, and for this purpose the convergent validity test was used. In this test, the degree of correlation of several items for a variable is estimated from the average variance extracted (AVE) of the latent variable, the CR, and subsequent quantifiable variables' loading (Bagozzi, Yi, \& Phillips, 1991; Chin, 1998). These studies suggest that the AVE of the study sample should be more than 0.5 , whereas the factor loading CR must not be under 0.7. In the following Table 3, the AVE and CR calculations are presented, and all the values are in the accepted range, which validates the study instrument.

Table 3. The validity test

\begin{tabular}{|l|c|c|c|c|}
\hline \multicolumn{1}{|c|}{ Variable } & Item & AVE & CR & Result/pass \\
\hline \multicolumn{5}{|c|}{ Independent variables } \\
\hline Green rewards & 2 & 0.57 & 0.72 & yes \\
\hline Green training & 3 & 0.65 & 0.85 & yes \\
\hline Green performance & 5 & 0.62 & 0.89 & yes \\
\hline Green recruitment & 3 & 0.59 & 0.81 & yes \\
\hline \multicolumn{7}{|c|}{ dependent variables } \\
\hline GWE & 6 & 0.58 & 0.83 & yes \\
\hline
\end{tabular}

\subsection{Total Model Fit}

It is recommended by (Hair, Black, \& Babin, 2010), that before making conclusions about the model, assessing goodness of fit indices to consider model diagnostics is required. These indices include model's chi-square $\left(\mathrm{X}^{2}\right)$, comparative fit index (CFI), the root mean square error of approximation (RMSEA), degree of freedom of the model (df), the Tucker-Lewis index (TLI), and the standardized root mean residual (SRMR). The accepted limits of mentioned indices are required to meet for the good model fit measure, and its recommended threshold values are $\mathrm{X} 2 / \mathrm{df}<3$, RMSEA $\leq .08$, CFI $>0.9$, TLI close to 1 (Bentler, 1990; Hair et al., 2010). Hence, it is necessary to assess the model fit before conducting final analysis. In Table 4, the key diagnostics are presented which supports the model fit of the dataset. The study model is shown in figure 1.

Table 4. Goodness of fit indices of the total model

\begin{tabular}{llllllll}
\hline Fit index & $\mathbf{X}^{\mathbf{2}}$ & $\mathbf{d f}$ & $\chi^{\mathbf{2}} / \mathbf{d f}$ & $\mathbf{T L I}$ & $\mathbf{C F I}$ & $\mathbf{R M S E A}$ & IFI \\
\hline Value & 215.45 & 124 & 1.737 & .93 & .96 & .06 & .93 \\
\hline
\end{tabular}

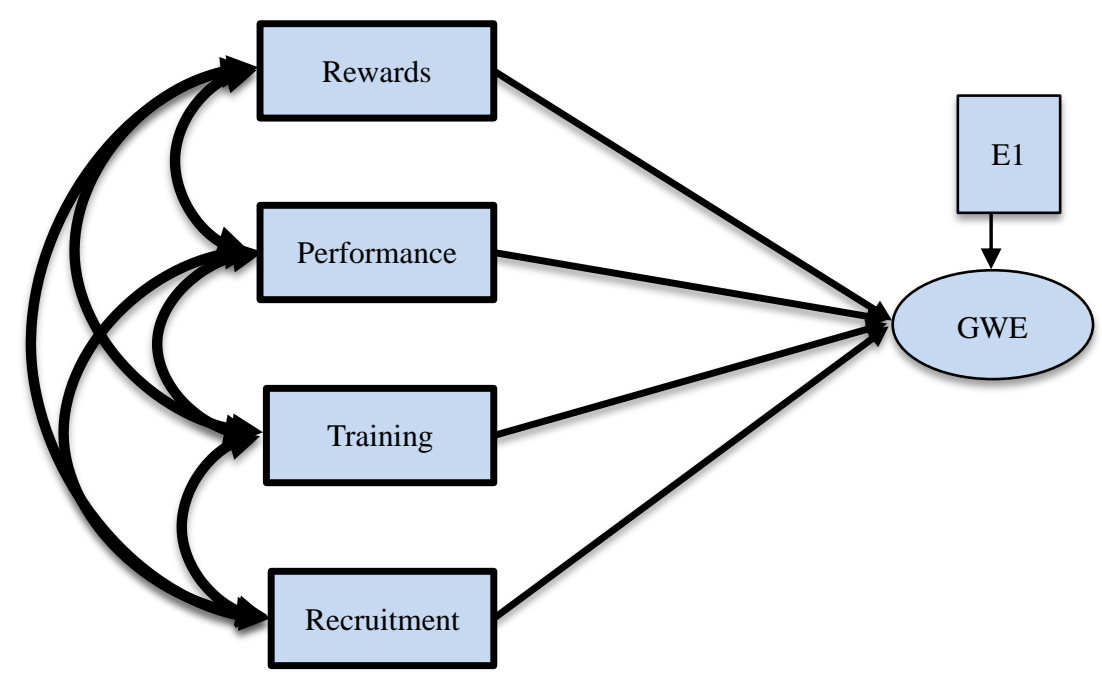

Figure 1. The study's model 


\section{Results}

\subsection{Descriptive Analysis}

Table 5 shows the personal traits of the respondents. $64.7 \%(\mathrm{n}=154)$ of the total participants are males and $35.3 \%$ $(\mathrm{n}=84)$ are females. Among these respondents around 52\% have work experience between 1-3 years. and most of them (around $43 \%$ ) falls under the category of operational and technical job level., while $64 \%$ of the respondent were between 26-34 years old.

Table 5. personal characteristics of the participants

\begin{tabular}{clcc}
\hline $\begin{array}{c}\text { Demographic } \\
\text { variables }\end{array}$ & \multicolumn{1}{c}{ Item } & Count & Percentage \% \\
\hline Gender & Male & 154 & 64,7 \\
& Female & 84 & 35,3 \\
\hline \multirow{3}{*}{ Job Tenure } & less than a year & 44 & 18.5 \\
& More than 1 year to 3 years & 124 & 52.1 \\
& More than 3 years to 6 years & 32 & 13.4 \\
& More than 6 years to 9 years & 30 & 12.6 \\
& More than 9 years & 8 & 3.4 \\
\hline \multirow{3}{*}{ Job Level } & Operational and technical (O\&T) & 104 & 43.7 \\
& Professional (P) & 82 & 34.5 \\
& Supervisor (S) & 24 & 10.1 \\
& Manager (M) & 28 & 11.8 \\
\hline \multirow{3}{*}{ Age } & (18 -24) years old & 24 & 10.1 \\
& (25-34) years old & 154 & 64.7 \\
& (35-44) years old & 46 & 19.3 \\
& (45-54) years old & 12 & 5.0 \\
& (55-64) years old & 2 & .8 \\
\hline
\end{tabular}

\subsection{Hypotheses Testing}

In the current study, Structural equation modeling (SEM) is used to test the formulated hypotheses. It is used to determine the relationship between the variables such as, independent variable over a dependent variable, using the covariance matrix. Additionally, the SEM test's main issue is to investigate the correlations amongst variables of the study since it can be used to determine the impact of the independent variables on the dependent ones. Moreover, SEM is used to evaluate the weight of the independent variables over dependent variable, and it will help in predicting the influence of the independent variables on the dependent variable, one advantage of SEM is the ability to conduct confirmatory factor analysis and regression analysis simultaneously (Kaplan, 2001). ). From Table 6-10, the results of SEM analysis are exhibited, and results were obtained by using AMOS 22 package. Moreover, figure 2 displays the study model which shows the path's estimate calculations by using SEM analysis.

Table 5. Regression weight

\begin{tabular}{ccccccc}
\hline & Path coefficient & & Estimates & S.E. & C.R. & P \\
\hline GWE & $\leftarrow$ & Reward & 0.760 & 0.37 & 2.036 & 0.04 \\
GWE & $\leftarrow$ & Recruitment & -0.762 & 0.46 & -1.628 & 0.104 \\
GWE & $\leftarrow$ & Training & 0.277 & 0.11 & 2.543 & 0.01 \\
GWE & $\leftarrow$ & Performance & 0.200 & 0.33 & 2.028 & 0.05 \\
\hline
\end{tabular}




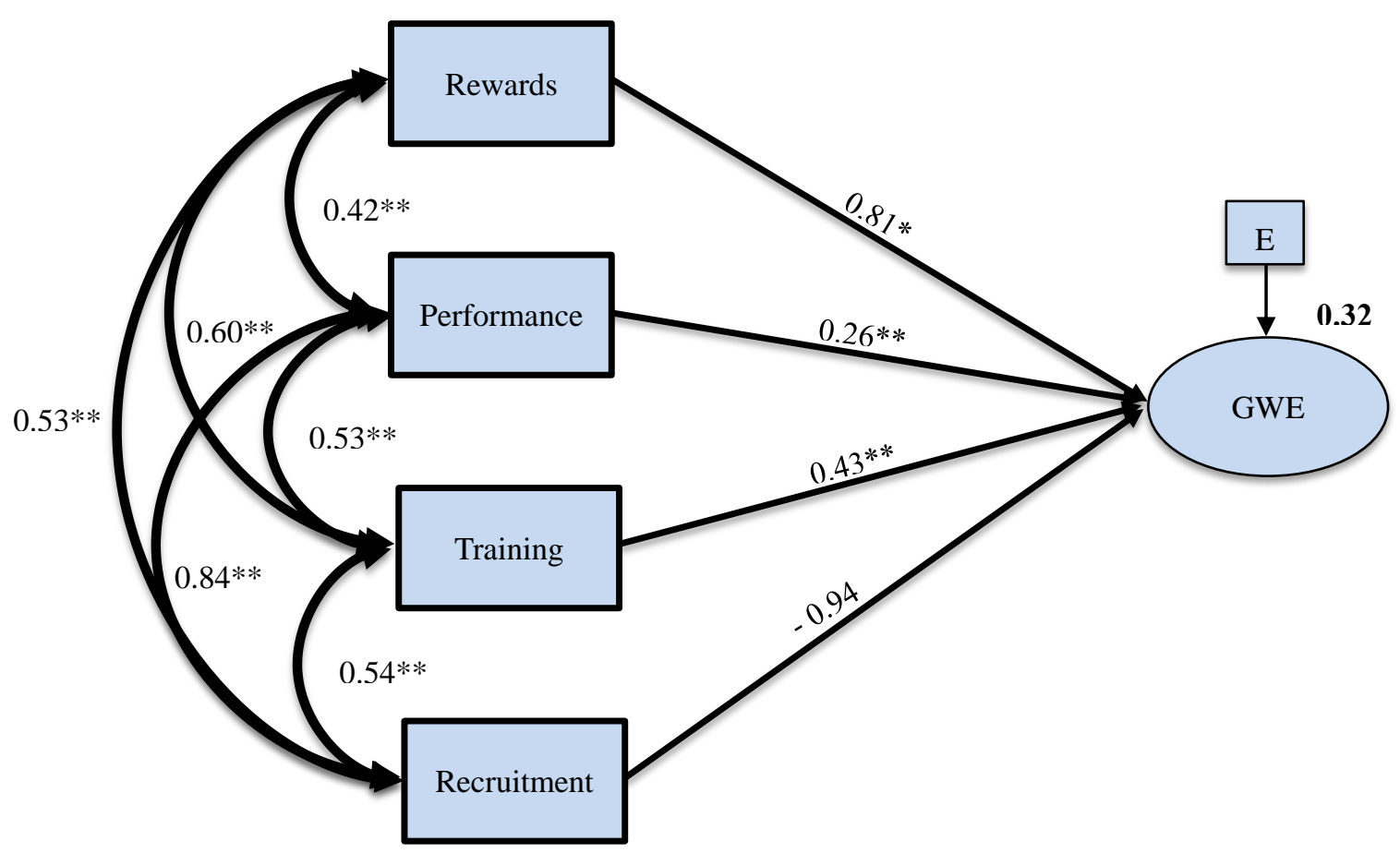

Note: 0.323 from Table 6; 0.81, 0.26, 0.43, -0.94 from Table 9; 0.54, 0.53, 0.42, 0.60, 0.84, 0.53 from Table 8 .

** $\mathrm{P}<0.001 . * \mathrm{P}<0.01$

Figure 2. The study model's results

Table 6. Squared multiple correlations

\begin{tabular}{cc}
\hline Variable & Estimate \\
\hline GWE & 0.323 \\
\hline
\end{tabular}

Table 7. Covariances

\begin{tabular}{lclclll}
\hline & Path coefficients & Estimate & S.E. & C.R. & P \\
\hline Performance & $<-->$ & Training & .257 & .044 & 5.804 & $* * *$ \\
Reward & $<->$ & Training & .258 & .049 & 5.281 & $* * *$ \\
Recruitment & $<-->$ & Training & .369 & .054 & 6.786 & $* * *$ \\
Reward & $<-->$ & Performance & .149 & .032 & 4.698 & $* * *$ \\
Reward & $<-->$ & Recruitment & .284 & .048 & 5.870 & $* * *$ \\
Recruitment & $<->$ & Performance & .234 & .041 & 5.749 & $* * *$ \\
$* * * \quad \mathrm{P}<0.001$ & & & & & &
\end{tabular}

Table 9. Correlations

\begin{tabular}{llll}
\hline \multicolumn{2}{l}{ Path Coefficients } & \multicolumn{3}{c}{ Estimates } \\
\hline Performance & $<-->$ & Training & .539 \\
Reward & $<->$ & Training & .607 \\
Recruitment & $<-->$ & Training & .541 \\
Reward & $<-->$ & Performance & .425 \\
Reward & $<-->$ & Recruitment & .534 \\
Recruitment & $<-->$ & Performance & .840 \\
\hline
\end{tabular}


Table 10. Standardized regression weights

\begin{tabular}{cccc}
\hline & Path coefficient & & Estimates \\
\hline GWE & $\leftarrow$ & Reward & .816 \\
GWE & $\leftarrow$ & Recruitment & -.957 \\
GWE & $\leftarrow$ & Training & .436 \\
GWE & $\leftarrow$ & Performance & .259 \\
\hline
\end{tabular}

\subsubsection{Study Main Hypotheses: Green HRM Can Predict GWE}

To explain the results of hypothesis testing, an assessment of independent variables was conducted to analyze whether these variables could forecast variance in the dependent variable. In Table 6, the squared multiple correlations were 0.323 , indicating that the dependent variable (GWE) variance could be predicted by the independent variables byb32.3 percent. Hence, it was validated that these predictors of GWE can pose significant positive influence on GWE. Referring to correlations table (No. 8), it indicates that the relationship was investigated between the independent variables, the strongest relationship between green recruitment and green performance management $(\mathrm{r}=0.84, \mathrm{P}<0.001)$, as well as between green rewards and green training $(\mathrm{r}=0.607, \mathrm{p}<0.001)$. The relationship between green recruitment and green training (GT) and green selection and recruitment (GSR) and green reward (GR) is very close to each other $(0.539, \mathrm{p}<0.001,0.534, \mathrm{p}<0.001)$.

Figure 2 presents the results of the direct path analysis. The results indicated that Green reward is positively associated with GWE ( $(=0.81, p=0.04)$, green performance is significantly positively associated with GWE ( $\beta$ $=0.26, \mathrm{p}<0.01)$, and green training is significantly positively associated with GWE $(\beta=0.43, \mathrm{p}<0.05)$. Therefore, hypotheses H1-1 H1-2 H1-3 respectively were supported. On the other hand, green recruitment was not significantly associated with GWE $(\beta=0.43, \mathrm{p}>0.05)$ therefore, Hypothesis H1-4 was rejected.

- The study model's econometric equation

On the basis of the results from table 6 (regression weight), constructed predictor's values equation is formed: Green reward (GR) $\beta=0.760, p=0.04$; green training (GT) $\beta=0.277, p=0.01$, green performance management (GPM) $\beta=0.200, \mathrm{p}<0.05$.

$$
\mathbf{G W E}=0.760(\mathbf{G R})+0.277(\mathbf{G T})+0.200(\text { GPM}) .
$$

\section{Discussion}

The present study explored the relationship between green HRM and green work engagement of the employees working in the energy sector in Hungary. The aim of the research was to analyse the influence of green HRM on the behaviour of the employees towards environmental practices and their work engagement. The results demonstrated that there exists a positive and significant relationship between having a green reward as green HR practice and GWE in the Hungarian energy companies. It was shown that green reward positively and significantly influences the GWE of an employee, Also, it is revealed that green human resources management has a significant positive relationship with GWE. Similarly, the influence of green training on GWE was evaluated, and it was observed that green training has a significant positive relationship with GWE. On contrary, the researchers found that green recruitment and selection were not predicting GWE significantly. These results are in line with previous studies that indicated that providing employees with green HRM practices will motivate them to pay more attention to environmental sustainability and enhance GWE (Ari et al., 2020). Achieving sustainability requires not only compliance with formal rules but also employee work engagement with voluntary green initiatives in the workplace. And this can result from having a Green HRM (Ren, Tang, \& E. Jackson, 2018). Applying sustainability in management practices helps in gaining different benefits for organizations like cutting costs, retaining and attract employees with green behaviors and awareness, and improve companies' business. One important aspect of these practices is green HRM which can effect on different green behaviors of employees especially their work engagement (Network for Business Sustainabilty, 2021). Applying suitable green HRM practices through its effect on GWE will improve the competitive advantage of these organizations (Arasli et al., 2020).

In accordance with our findings (Aboramadan, 2020) found that green HRM can predict GWE significantly which in turn causes some green individual outcomes, however the mentioned study used green HRM as one variable without mentioning each practice. In contrast, the current study attempt to provide more detailed 
explanation of the role of each practice of green HRM to predict GWE.

The results of this study suggests that there exists a significant positive relationship between the selected variables in this model. In other words, the combination of the selected green HRM practices significantly predicts the GWE, $\mathrm{R}^{2}=0.323$, which means that these selected independent variables could explain $32.3 \%$ of the variation of GWE. Therefore, there are still other variables that can explain the variation of GWE such as green development, green empowerment, green work-life balance (Ren et al., 2018). The study's results also converge partially with (Cantor et al., 2012), and their study did not support the role of green rewards in predicting GWE. However, it was reported that supervisor's support could motivate an employee to have higher level of GWE.

The interpretation of the econometric equation of the model indicated that if each of GR, GT, GPM is increased by ten units then it will increase GWE by $(7.6,2.77$, and 2.00) units respectively. The researchers could conclude that green rewards are the most effective and strong variable in predicting GWE. The second strongest predictor according to the results of the current study is green training that influences GWE. These results reveal that it is necessary for employees to receive some HR green practices like taking special green training or receiving some rewards to influence their GWE. Furthermore, this study supports the role of green performance management in influencing the GWE, but it was that its impact is not high in comparison to other variables. These results are similar to the results of a recent study that indicated that these three practices are positively associated with work engagement (Arasli et al., 2020).

Finally, the study findings found that green recruitment was not significantly affects GWE, and that might be because the green recruitment practices were not clearly conveyed to the employees at the time of their recruitment and selection. As green recruitment was not significantly associated with GWE in our findings, it contradicts the findings of the study conducted by (Ari et al., 2020), who found that it is positively associated with GWE.

\section{Conclusions}

This study highlighted the understanding of green work engagement and the variables that influence it. The study aimed to study the impact of perceived green HRM practices to enhance green work engagement. SEM was used to analyze the data and to measure the relationship between the study variables. This study focused on four different green HRM practices and explored the effects of each one of them separately on green work engagement. The study indicated that green rewards, green training, and green performance management are important predictors of green work engagement whereas green recruitment was not significantly associated with green work engagement. Among these variables, the study indicated that green rewards had the highest impact on predicting green work engagement. The results support the researchers' argument that green HRM practices can predict green work engagement in Hungary's energy companies.

This study provided novel results and expanded the knowledge regarding green work engagement since very few recent studies have focused on it. It attempts to enrich the literature and to bridge the research gap on the relationship between the studied GHRM practices and green work engagement. The study also supported the results of the previous studies which focused on same variables of the study and it emphasized the validity of the measures scales.

\section{Limitations}

Even though the results were satisfying compared to the hypothesis, several limitations were encountered throughout the research. First and most important, the data was collected from only three companies. Not all employees were helpful in answering the questionnaires, which caused the sample to be relatively small $(\mathrm{N}=238)$ for quantitative analysis. Another important limitation was the lack of literature that built the relationship between green HRM and GWE since the last variable is a relatively new term for research.

\section{Recommendations}

The authors recommend companies that want to enhance their employees' green work engagement throughout implementing green human resources management practices within their companies, especially by focusing on green rewards systems and green training, which may result in an enhanced GWE. The authors also recommend the companies to give attention to green performance since it could predict at low-level GWE.

As practical recommendations, it is implied on HR managers to employ and execute green management practices at each, and every hierarchical level of their organization and it is required for them as well to follow these practices individually. It implies that HR managers and the organizations should develop and perform such green practices that will provide a point of reference for the employees to follow them, and as a result it will generate 
strong work engagement of employees. It should be the role of HR managers to provide and simplify green management to their employees to make them accomplish green HRM practices that will add to their green values and green work engagement.

This study explicitly focused on four green HRM practices like green training, green rewards, green recruitment, and green performance. Therefore, it is recommended for future studies to incorporate other green HRM practices in their model for better understanding of the influence of such practices on green behaviors of employees. These additional practices could include green development, green work-life balance, green empowerment etc., and should specifically focus on employee's engagement as it is crucial to achieve competitive advantage. Moreover, future research can apply the comprehensive model of this study in other sectors to explain its relevance in the companies with different fields and work environment. Also, the study focused only on the direct effects of GHRM on GWE however, there could be some factors that affect this relationship related to organizational climate or personal traits of the employees. Therefore, it would be interesting for future researchers to focus on these variables as moderators or mediators in this relationship.

\section{References}

Ababneh, O. M. A. (2021). How do green HRM practices affect employees' green behaviors? The role of employee engagement and personality attributes. Journal of Environmental Planning and Management, 1-23. https://doi.org/10.1080/09640568.2020.1814708

Aboramadan, M. (2020). The effect of green HRM on employee green behaviors in higher education: the mediating mechanism of green work engagement. International Journal of Organizational Analysis, ahead-of-print (ahead-of-print). https://doi.org/10.1108/ijoa-05-2020-2190

Ahmad, S. (2015). Green Human Resource Management: Policies and practices. Cogent Business \& Management, 2(1), 1030817. https://doi.org/10.1080/23311975.2015.1030817

Ahmed, U., AlZgool, M. R. H., \& Shah, S. M. M. (2019). The impact of green human resource practices on environmental sustainability. Polish Journal of Management Studies, 20. https://doi.org/10.17512/pjms.2019.20.1.01

Aktar, A., \& Islam, Y. (2019). Green Human Resource Management Practices and Employee Engagement: Empirical Evidence from RMG sector in Bangladesh. https://doi.org/10.2139/ssrn.3363860

Alshaabani, A., \& Rudnak, I. (2020). Impact of diversity Management Practices on Organizational Climate- An Egyptian Study. Vadyba Journal of Management, 1(36), 7-17. https://doi.org/10.38104/vadyba.2020.01

Ángel del Brío, J., Junquera, B., \& Ordiz, M. (2008). Human resources in advanced environmental approaches-a case analysis. International Journal of Production Research, 46(21), 6029-6053. https://doi.org/10.1080/00207540701352094

Arasli, H., Nergiz, A., Yesiltas, M., \& Gunay, T. (2020). Human Resource Management Practices and Service Provider Commitment of Green Hotel Service Providers: Mediating Role of Resilience and Work Engagement. 12(21), 9187. https://doi.org/10.3390/su12219187

Ari, E., Karatepe, O. M., Rezapouraghdam, H., \& Avci, T. J. S. (2020). A Conceptual Model for Green Human Resource Management: Indicators, Differential Pathways, and Multiple Pro-Environmental Outcomes. 12(17), 7089. https://doi.org/10.3390/su12177089

Arulrajah, A. A., Opatha, H., \& Nawaratne, N. (2015). Green human resource management practices: A review. Sri Lankan Journal of Human Resource Management, 5(1). https://doi.org/10.4038/sljhrm.v5i1.5624

Bagozzi, R. P., Yi, Y., \& Phillips, L. W. (1991). Assessing Construct Validity in Organizational Research. Administrative Science Quarterly, 36(3), 421-458. https://doi.org/10.2307/2393203

Bakker Arnold, B., \& Demerouti, E. (2008). Towards a model of work engagement. Career Development International, 13(3), 209-223. https://doi.org/10.1108/13620430810870476

Bentler, P. M. (1990). Comparative fit indexes in structural models. Psychol Bull, 107(2), 238-246. https://doi.org/10.1037/0033-2909.107.2.238

Cantor, D. E., Morrow, P. C., \& Montabon, F. (2012). Engagement in Environmental Behaviors Among Supply Chain Management Employees: An Organizational Support Theoretical Perspective. Journal of Supply Chain Management, 48(3), 33-51. https://doi.org/10.1111/j.1745-493X.2011.03257.x

Casey, D., \& Sieber, S. (2016). Employees, sustainability and motivation: Increasing employee engagement by addressing sustainability and corporate social responsibility. Research in Hospitality Management, 6(1), 
69-76. https://doi.org/10.2989/RHM.2016.6.1.9.1297

Chaudhary, R. (2019). Green human resource management in Indian automobile industry. Journal of Global Responsibility. https://doi.org/10.1108/JGR-12-2018-0084

Chaudhary, R. (2020). Green human resource management and employee green behavior: an empirical analysis. Corporate Social Responsibility Environmental Management, 27(2), 630-641. https://doi.org/10.1002/csr.1827

Chin, W. W. (1998). Commentary: Issues and Opinion on Structural Equation Modeling. MIS Quarterly, 22(1), vii-xvi.

Curkovic, S., Melnyk, S. A., Handfield, R. B., \& Calantone, R. (2000). Investigating the linkage between total quality management and environmentally responsible manufacturing. IEEE Transactions on Engineering Management, 47(4), 444-464. https://doi.org/10.1109/17.895340

Daily, B. F., \& Huang, S. C. (2001). Achieving sustainability through attention to human resource factors in environmental management. International Journal of Operations \& Production Management, 21(12), 1539-1552. https://doi.org/10.1108/01443570110410892

DuBois, C. L., \& Dubois, D. A. J. H. R. M. (2012). Strategic HRM as social design for environmental sustainability in organization. Human Resource Management, 51(6), 799-826. https://doi.org/10.1002/hrm.21504

Dumont, J., Shen, J., \& Deng, X. (2017). Effects of Green HRM Practices on Employee Workplace Green Behavior: The Role of Psychological Green Climate and Employee Green Values. Human Resource Management, 56(4), 613-627. https://doi.org/10.1002/hrm.21792

Goswami, T., \& Ranjan, S. (2015). Approach to sustainability in current scenario. Journal for Studies in Management and Planning, 1(4), 250-259.

Haddock-Millar, J., Sanyal, C., \& Müller-Camen, M. (2016). Green human resource management: a comparative qualitative case study of a United States multinational corporation. The International Journal of Human Resource Management, 27(2), 192-211. https://doi.org/10.1080/09585192.2015.1052087

Hair, J. F., Black, W. C., \& Babin, B. J. (2010). Multivariate Data Analysis: A Global Perspective: Pearson Education.

Halawi, A., \& Zaraket, W. (2018). Impact of Green Human Resource Management on Employee Behaviour. Journal of Applied Business Research, 6.

Hobfoll, S. E. (2001). The Influence of Culture, Community, and the Nested-Self in the Stress Process: Advancing Conservation of Resources Theory. Applied Psychology, 50(3), 337-421. https://doi.org/10.1111/1464-0597.00062

Jabbar, M. H., \& Abid, M. (2015). A study of green HR practices and its impact on environmental performance: A review.

Jabbour, C. J. C. (2011). How green are HRM practices, organizational culture, learning and teamwork? A Brazilian study. Industrial and Commercial Training, 43(2), 98-105. https://doi.org/10.1108/00197851111108926

Jabbour, C. J. C. (2013). Environmental training in organisations: From a literature review to a framework for future research. Resources, Conservation and Recycling, 74, 144-155. https://doi.org/10.1016/j.resconrec.2012.12.017

Jabbour, C. J. C., Santos, F. C. A., \& Nagano, M. S. (2008). Environmental management system and human resource practices: is there a link between them in four Brazilian companies? Journal of Cleaner Production, 16(17), 1922-1925. https://doi.org/10.1016/j.jclepro.2008.02.004

Jabbour, C. J. C., Santos, F. C. A., \& Nagano, M. S. (2010). Contributions of HRM throughout the stages of environmental management: methodological triangulation applied to companies in Brazil. The International Journal of Human Resource Management, 21(7), 1049-1089. https://doi.org/10.1080/09585191003783512

Jackson, S. E., Renwick, D. W. S., Jabbour, C. J. C., \& Muller-Camen, M. (2011). State-of-the-Art and Future Directions for Green Human Resource Management: Introduction to the Special Issue. 25(2), 99-116. https://doi.org/10.1177/239700221102500203

Jerez-Gómez, P., Céspedes-Lorente, J., \& Valle-Cabrera, R. (2005). Organizational learning and compensation 
strategies: Evidence from the Spanish chemical industry. 44(3), 279-299. https://doi.org/10.1002/hrm.20071

Jyoti, K. (2019). Green HRM-People Management Commitment to Environmental Sustainability. Paper presented at the Proceedings of 10th International Conference on Digital Strategies for Organizational Success. https://doi.org/10.2139/ssrn.3323800

Kane, A. (2011). Green recruitment, development and engagement. In D. Bartlett (Ed.), Going green: The psychology of sustainability in the workplace (pp. 6). London: Metropolitan University

Kaplan, D. (2001). Structural Equation Modeling. In N. J. Smelser \& P. B. Baltes (Eds.), International Encyclopedia of the Social \& Behavioral Sciences (pp. 15215-15222). Oxford: Pergamon. https://doi.org/10.1016/B0-08-043076-7/00776-2

Kim, Y. J., Kim, W. G., Choi, H. M., \& Phetvaroon, K. (2019). The effect of green human resource management on hotel employees' eco-friendly behavior and environmental performance. International Journal of Hospitality Management, 76, 83-93. https://doi.org/10.1016/j.ijhm.2018.04.007

Luu Tuan, T. (2017). CSR and organizational citizenship behavior for the environment in hotel industry: The moderating roles of corporate entrepreneurship and employee attachment style. International Journal of Contemporary Hospitality Management, 29(11), 2867-2900. https://doi.org/10.1108/IJCHM-02-2016-0080

Naz, F., Oláh, J., Vasile, D., \& Magda, R. (2020). Green Purchase Behavior of University Students in Hungary: An Empirical Study. Sustainability, 12(23), 10077. https://doi.org/10.3390/su122310077

Network for Business Sustainabilty. (2021). Employee Engagement and Going Green. Retrieved from https://www.nbs.net/articles/engaging-employees-in-going-green

North, K. (1997). Environmental Business Management: An Introduction: International Labour Office.

Ojo, A. O., \& Raman, M. (2019). Role of Green HRM Practices in Employees' Pro-environmental IT Practices. Paper presented at the New Knowledge in Information Systems and Technologies, Cham. https://doi.org/10.1007/978-3-030-16181-1_64

Opatha, H. H. D. N. P., \& Arulrajah, A. A. (2014). Green Human Resource Management: Simplified General Reflections. International Business Research, 7(8). https://doi.org/10.5539/ibr.v7n8p101

Paillé, P., Chen, Y., Boiral, O., \& Jin, J. (2014). The Impact of Human Resource Management on Environmental Performance: An Employee-Level Study. Journal of Business Ethics, 121(3), 451-466. https://doi.org/10.1007/s10551-013-1732-0

Pham, D. D. T., Paillé, P., \& Halilem, N. (2019). Systematic review on environmental innovativeness: A knowledge-based resource view. Journal of Cleaner Production, 211, 1088-1099. https://doi.org/10.1016/j.jclepro.2018.11.221

Ranasinghe, V., \& Welmilla, I. (2020). Green Employee Engagement. In Contemporary Developments in Human Resource Management. Sri Lanka: Department of Human Resource Management, University of Kelaniya.

Rani, S., \& Mishra, K. (2014). Green HRM: Practices and strategic implementation in the organizations. International Journal on Recent Innovation Trends in Computing Communication, 2(11), 3633-3639. https://doi.org/10.17762/ijritcc.v2i11.3525

Ren, S., Tang, G., \& E. Jackson, S. (2018). Green human resource management research in emergence: A review and future directions. Asia Pacific Journal of Management, 35(3), 769-803. https://doi.org/10.1007/s10490-017-9532-1

Renwick, D., Redman, T., \& Maguire, S. (2008). Green HRM: A review, process model, and research agenda. University of Sheffield Working Paper, 1, 1-46.

Retrieved from https://www.sheffield.ac.uk/polopoly_fs/1.120337!/file/Green-HRM.pdf

Renwick, D., Redman, T., \& Maguire, S. (2013). Green Human Resource Management: A Review and Research Agenda. International Journal of Management Reviews, 15(1), 1-14. https://doi.org/10.1111/j.1468-2370.2011.00328.x

Saratun, M. (2016). Performance management to enhance employee engagement for corporate sustainability. Asia-Pacific Journal of Business Administration, 8(1), 84-102. https://doi.org/10.1108/APJBA-07-2015-0064

Schaufeli, W. B., Salanova, M., González-romá, V., \& Bakker, A. B. (2002). The Measurement of Engagement and Burnout: A Two Sample Confirmatory Factor Analytic Approach. Journal of Happiness Studies, 3(1), 
71-92. https://doi.org/10.1023/A:1015630930326

Sekaran, U., \& Bougie, R. (2016). Research Methods For Business: A Skill Building Approach: Wiley.

Tang, G., Chen, Y., Jiang, Y., Paillé, P., \& Jia, J. (2018). Green human resource management practices: scale development and validity. Asia Pacific Journal of Human Resources, 56(1), 31-55. https://doi.org/10.1111/1744-7941.12147

Unsworth, K. L., Dmitrieva, A., \& Adriasola, E. (2013). Changing behaviour: Increasing the effectiveness of workplace interventions in creating pro-environmental behaviour change. Journal of Organizational Behavior, 34(2), 211-229. https://doi.org/10.1002/job.1837

Welmilla, I., \& Ranasinghe, V. (2020). Green Employee Engagement. In Contemporary Developments in Human Resource Management (pp. 77-86). Sri Lanka: Department of Human Resource Management, University of Kelaniya.

Yusoff, Y. M. (2016). For a greener human resource management. International Journal of Humanities and Management Sciences, 4(2), 190-194.

Ziegler, A., \& Seijas Nogareda, J. (2009). Environmental management systems and technological environmental innovations: Exploring the causal relationship. Research Policy, 38(5), 885-893.

https://doi.org/10.1016/j.respol.2009.01.020

Zoogah, D. B. (2011). The dynamics of Green HRM behaviors: A cognitive social information processing approach. German Journal of Human Resource Management, 25(2), 117-139.

https://doi.org/10.1177/239700221102500204

\section{Copyrights}

Copyright for this article is retained by the author(s), with first publication rights granted to the journal.

This is an open-access article distributed under the terms and conditions of the Creative Commons Attribution license (http://creativecommons.org/licenses/by/4.0/). 